\title{
The Utilization of Email and WhatsApp among Muhammadiyah Regional Leaders in Medan City
}

\author{
Winda Kustiawan', Syukur Kholil'², Yusnadi² \\ ${ }^{1}$ Ph.D Student in State Islamic University of North Sumatera (UINSU), Medan, Indonesia \\ ${ }^{2}$ Lecturer in State Islamic University of North Sumatera (UINSU), Medan, Indonesia \\ wildanansori22@gmail.com
}

\begin{abstract}
The aim of this research is to describe the utilization of email and whatsapp among Muhammadiyah Regional Leaders in Medan City. This research uses descriptive qualitative approach. The results show that the use of email and whatsapp among Muhammadiyah Regional Leaders in Medan City that they understand the reasons for using email and whatsapp as a means of organizational information, the considerations are Trend, Application, Features, Fast and Capacity. Media other than email and whatsapp, they use Facebook, Twitter, Line, Instagram and Messenger. Effects of whatsapp Utilization Used because of its speed, its distribution are easy and can be done selectively. Next the categorization of the utilization of whatsapp used by Muhammadiyah Leaders of Medan City that fast access, low cost, features, more effective and faster information delivered so that it becomes a strategic customer. The advantages of using whatsapp are more trends, easy coordination, more convenience and easier and cheaper. So from this it facilitates organizational activities, connecting quickly with other leaders and mastering the media as a source of effective information and communication within the organization. The messages which is obtained by the Muhammadiyah Regional Head of Medan City from email and whatsapp is that the Leaders can understand the characteristics of Email usage and whatsapp.
\end{abstract}

Keywords : Email; WhatsApp; Muhammadiyah Leaders.

\section{Introduction}

In the current era of globalization, technology is developing very rapidly. This is closely related to human needs for information and technology. To complement their needs, humans use various methods and media. One human need is the need for information. This information is obtained through mass media and non-mass media. The mass media consists of television, radio, newspapers, magazines, tabloids and films. At present, the communication media that is growing very rapidly is online media. With online media, information from around the world can be obtained. High speed in providing information, making online media widely used by the public at this time.

After the invention of computers in the 1960s and continued to develop until the 1990s resulting in internet technology, experts were astonished at the rapid development of this technology. The internet is so amazing and so fast developing with the variants of its programs that make this earth in the technology of strangulation. The internet has developed into a technology that is not only capable of transmitting various information, but has also been able to create a new world and the reality of human life, namely a materialistic reality that is created in virtual life. This reality is not mystical, not imaginary, but truly realistic.

At present, the internet is very important and has an extensive network, connecting the simplest personal computers, not least by the leadership of Medan's Muhammadiyah Regional Leadership. The services provided by the internet provide e-mail, Netnews, Telnet, File Transfer Protocol (FTP) and the world wide web or www, where the most widely used are email and www. Other developments of the internet are search engines and traces, such as 
browsers and search engines. It has a multimedia hyperlink function, which helps users to search quickly and systematically. Users can also move between existing relationships, read, listen, and choose-go-go in the library. Moreover, internet users can search for relevant information by filtering large data sets. Jobs sought, supported, whichever receives no longer accepts what is reported, received, or sends relevant information.

The need for social involvement is very important for all levels of society, regardless of age, position and social status, especially for community groups. All community groups need the media as a means of communication to be able to communicate with related group members and must be face to face, such as messenger applications such as Line, WhatsApp, Kakao Talk, to liteBIG.

The email application and WhatsApp are the most popular applications, which are used by various types of community organizations in Indonesia, not least by the Muhammadiyah Regional Leaders of Medan City. Email and WhatsApp applications become something ideal to use as a means of delivering messages and even becoming news media, Islamic studies and information channels in the Muhammadiyah Regional Leadership Office of Medan City, Muhammadiyah Branch leaders throughout Medan and Muhammadiyah Branch Heads throughout Medan City.

\section{Review of Literatures}

\subsection{Organizational Theory}

Organizations are basically a number of people who work together on a regular basis to achieve a goal that is difficult to achieve if done individually, people in the organization work together and work together in working groups in accordance with their respective fields of work, in other words, the group plays an important role in the organization and is a reflection of organizational performance.

Organization is an activity of compiling and forming work relationships between people so that a business entity is realized in achieving its stated goals. In organizing there is a division of tasks, authorities, and responsibilities in detail according to fields and parts, so that there is a harmonious and smooth relationship to achieve the stated goals.

The term organization has two general meanings. The first organization is defined as an institution or functional group, for example, a company, a school, an association, government agencies. Second, referring to the organizing process that is how work is organized and allocated among members, so that the organization's goals can be achieved effectively. While the organization itself is defined as a collection of people with a collaborative system clearly regulated who runs what, who is responsible for who, the flow of communication, and focuses resources on the goal.

\subsection{Information Seeking Theory}

Information Seeking, which describes search, sensing, and information processing, is said to have the roots of social psychology thinking about attitudes. One of the main assumptions is that people tend to avoid information that is incompatible with their image of reality because the information can be dangerous.

Information seeking is a process or activity that tries to get information and technology both in the human context. Finding information related to, but not yet different, information retrieval (IR). Information seeking is also interpreted as an effort to find information in general, 
and information searching is an activity specifically looking for certain information which has been more planned and directed. In simple terms, information seeking involves searching, retrieving, acknowledging, and applying meaningful content. This search can be explicit or implicit, search may be the result of a specific or accidental strategy, the information generated may be embraced or rejected, the whole experience can be done through a logical conclusion or stopped halfway, and there may be millions of other potential results.

Information seeking has been seen as a cognitive exercise, as a social and cultural exchange, as a discrete strategy applied when facing uncertainty, and as a basic requirement of humanity where all individuals exist. In fact, information behavior may be a more appropriate term, rather than seeking information, to best describe the multi-faceted information relationships in human life, a relationship that can include both actively seeking through formal information channels and various other attitudes and actions, including skepticism and ambivalence. Kuhlthau explains the process of information seeking as initiation, selection, exploration, formulation, collection, and presentation.

\subsection{Email}

Email stands for electronic mail, or in the Indonesian language Electronic Mail, which is a letter that sends using electronic means, namely through an internet network, by e-mail or email, someone can send text, images, or even send an application or file to someone who is of course also has e-mail (e-mail) in a very short time. Because this e-mail uses the internet network, the address also adapts to e-mail service providers on the internet. For example, email service providers are http: //www.mail.yahoo.com,http: //www.mail.google.com, and others.

Email also has functions, namely: 1. Media communication: E-mail or electronic mail is a communication medium that is usually done in a persoal or public (community). 2. Delivery media: With e-mail you can send data to the entire world and of course the sender and the sender of data both use e-mail addresses, not home addresses. Not only that, by using e-mail you can send data to many people in just minutes or even seconds. 3. Effective, efficient and inexpensive: Conducting data transmission via e-mail is very effective, efficient and inexpensive. That is, you don't need to go out of the house and go to the post office just to send photos or job applications. Enough through your internet connection and e-mail address, shipping will quickly arrive at the destination address and do not need to be expensive. 4. Media promotion: If you can have a business on the internet or an online business, you can send product promotions to your customers by utilizing existing customer e-mail lists. 5. Media information: Through e-mail, you can get the latest information from around the world that you want by becoming a customer of information from the media that you specify. 6. Create a blog or website: With e-mail you can create blogs and websites. 7. Social media: With e-mail, you can establish relationships with friends or other people. Either use e-mail itself or through social networks like Facebook, Twitter or Google.

\subsection{WhatsApp}

The progress of communication technology from time to time continues to experience significant progress. This happens because the rapid development of technology can make it easier for humans to communicate according to their needs. The message to be conveyed by the communicator to the communicant can be immediately delivered through technology. One technology that is currently popular is a smartphone. 
Smartphones are mobile phones in which there are applications that can be used for communication. The various applications available are very easy and can work quickly. Some applications that can be used to communicate are Whatsapp, BBM, Kakao Talk Meessenger, WeChat, Line Messenger, Skype, and many other applications.

Thus, smartphone users increasingly show very high numbers. The digital marketing research agency Emarketer estimates that in 2018 there will be more than 100 million active smartphone users in Indonesia. Users also vary, ranging from children, adolescents, adults, to middle-aged. They are very spoiled with the applications contained in the smartphone. One of the most popular applications for communication is whatsapp app.

The WhatsApp application is currently favored by smartphone users. WhatsApp users around the world have even recorded around 1 billion users every day and there are also around 1.3 billion that use this application every month. The ease of communicating through the application makes it easier for users to exchange messages, send pictures, send voices, send documents, and send locations where we are. Given this application is one application that is very easy to use as a function of mobile phones in general. But in the WhatsApp application there are several advantages.

In the world of organizations and the world of work, this WhatsApp application is often used for communication. Whether it's used for an interest or used for organizational, entertainment or regular communication purposes. Besides that there are many more advantages that can be utilized through this application. Because of its convenience, this application is much in demand, especially in the world of community organizations. Even each of the people in the world of social organizations, makes smartphones as a must-have tool as a communication tool, especially communication via WhatsApp.

Communication is divided into two parts, namely, direct communication and indirect communication. Direct communication is a communication that is carried out directly (face to face), while indirect communication is a communication carried out through an intermediary. Communication activities carried out through the help of a tool such as the WhatsApp application on a smartphone are a type of indirect communication. In every communication activity, of course there is ethics that must be considered. The importance of communication needed in various ways makes communicators and communicants forget about ethics. Though ethics is very necessary in every corner of life, especially in terms of communication.

\section{Research Methods}

This research is a qualitative research. Qualitative research is the procedure of research that produces descriptive data. That is using a qualitative approach or often called the Naturalistic method because this research is used in natural conditions. In addition qualitative research is a study that produces written or oral data. Thus, the context of the data source that the researcher used in this study was a descriptive statement from a concentrated informant. Data is obtained through observation, interviews, and reviewing documents relating to the problems to be carried out in the study.

This study uses a qualitative descriptive method. Descriptive research is a study that is intended to provide an overview of the state of the subject / object of research as it is. Research that seeks to explain the problem solving that is now based on data. When there are illustrations that lead to calculations in the form of numbers (quantitative), then things are intended only to sharpen the analysis and strengthen the research argument. 
Qualitative research is research that gets discoveries in unexpected research and builds new theoretical frameworks. Qualitative research usually pursues verbal data that is more representative of phenomena and not numbers filled with percentages and obtained from the field. This research is qualitative because it does not make calculations, statistics, etc., but uses scientific emphasis or research that results in discoveries that are not achieved by statistical procedures or by other means of quantification.

The location to be investigated by that is on the Jalan Mandala By Pass in Medan, namely the Regional Head of Muhammadiyah Medan City. The selection of research locations at the Muhammadiyah Regional Leadership in Medan City is based on certain considerations. The first consideration is the element of affordability of research locations by researchers, both in terms of energy, funding and in terms of time efficiency. The implementation of the research chosen does not cause problems in relation to energy capacity. One thing that is very helpful in conducting research at this chosen location is the problem of funding. Research does not require a larger field study cost compared to research elsewhere. In addition, the selection of the location of this study can provide time efficiency and still be able to carry out the main tasks of the researcher. There are other reasons that are no less important and more basic considerations in choosing the location of this study. these considerations are the special characteristics inherent in the chosen setting. The time of the study was carried out for two months, namely January and February 2019.

\section{Discussion}

Serving as Chair of the Muhammadiyah Regional Chair of Medan City for 3 years from 2015, there have been many information and communication tools used by Mr. Anwar Sembiring, one of whom is a mobile phone (HP). The function of the cellphone for Anwar Sembiring can call send messages and also use social media. During this time Anwar Sembiring used social media Facebook to socialize with relatives, family or office friends, and to send documents using e-mail, but after the new social media trend, whatsapp, Anwar Sembiring also used it even though it was a trend but because of the application, the features, speed and capacity are good so he uses it more for now.

Similar to what was expressed by Mr. Anwar Sembiring as chairman of the Muhammadiyah Regional Head of Medan City, Mr. Hasrat Efendi Samosir, Secretary of the Muhammadiyah Regional Head of Medan City also stated the same thing, namely:

"I use a lot of social media such as BBM, Line, FB, and Email. Then the last few years I used WhatsApp. Initially I used e-mail and whatsapp as a trend, but because the facilities provided by WhatsApp are very good where features, speed and capacity are very wide compared to SMS in delivering messages faster. Especially if the network is available Wifi in the office using WhatsApp is getting smoother without us having to have a quota, just enough Office Wifi.

The use of e-mail and whatsapp for providing information is considered quite effective both in terms of distance, time and cost. Moreover, email and WhatsApp is an instant application that provides facilities to facilitate the delivery of messages, chat or inter-platform conversations commonly used by smartphone users to send text, photo, video and audio messages. The use of email and WhatsApp with better features and capacity and speed than other social media was also felt by Mr. Hasrat Efendi Samosir: 
"I have several social media accounts including Path, WhatsApp, Instagram and e-mail and this really helps me a lot if there is information that I need. In social media I don't have much time, only I use it for my work. Using whatsapp does not need to stay open the application, let alone send messages or other information very quickly. I am including slow using WhatsApp starting in 2015 but because the application is better than the others we can send photos or pictures and even videos and this is used for work so now I use Whatsapp more often, compared to Facebook it takes me a lot of time. "

From the words of Mr. Hasrat Efendi Samosir that social media that help a lot of work is email and WhatsApp because the application is good and can make it easier to communicate. Then get information, besides e-mail and whatsapp, he also uses Facebook, line and Instagram.

The same thing was stated by other informants namely Mr. Fardinal and Mr. M. Nur that they had previously used several social media to socialize with relatives, friends and even family including Facebook, BBM, LINE, Facebook and Twitter and they usually use email to send data or documents they. But after a new and very practical social media trend, which is WhatsApp which has more sophisticated features and the speed of sending messages or information and a large capacity in storing or processing data, they use WhatsApp a lot, although according to Pak Anwar Sembiring who previously used facebook to send photos because there is no verification more privacy than WhatsApp which is directly connected with number contacts so it's easy for someone to know other people. However, because WhatsApp has a greater capacity to process and store data, it often uses e-mail and WhatsApp to send documents.

Based on the results of interviews with the four informants who were all three administrators of the Medan City Muhammadiyah Regional Leader and one Head of Office and also the WhatsApp Group Admin. The social media they use both to socialize and to support their work. Namely email and whatsapp. The social media they use email and WhatsApp include Facebook, Line, Instagram and Messenger. But in supporting and helping with their assignments and work they are currently using WhatsApp more. Initially they used whatsapp as Trand, but finally they realized that social media e-mail and WhatsApp are widely used because they have good capacity, features and speed compared to other social media. And this is also the reason for using the info group to communicate with other office friends. And then formed a group called the Info Group Program Subdivision. For more details the reasons why they use email and WhatsApp more can be seen in the following table:

Table 1. Reasons for Using Email and WhatsApp

\begin{tabular}{|l|l|l|l|l|l|l|}
\hline NO & Name & Trend & Application & Feature & Fast & Capacity \\
\hline 1. & Drs.Anwar Sembiring, M.Pd & $*$ & $*$ & $*$ & $*$ & $*$ \\
\hline 2. & Dr. Hasrat Efendi Samosir, MA & $*$ & $*$ & $*$ & $*$ & $*$ \\
\hline 3. & Rafdinal, S. Sos, M. Ap & & $*$ & $*$ & $*$ & $*$ \\
\hline 4. & Muhammad Nur & $*$ & $*$ & $*$ & $*$ & $*$ \\
\hline
\end{tabular}

From the data in the table above, it can be seen that using WhatsApp turns out the benefits are far more effective. Informants use WhatsApp based on trend or popularity. And the popularity of social media is supported by easy applications. The way is just by downloading content services which will then automatically connect as friends if the person's number is already in our smart phone contact. The features, speed and capacity owned by WhatsApp social media are also the main reasons for the informants to use this application. 
From the interview results above, it can also be revealed that besides the WhatsApp media the informants also use other social media in socializing and also as a supporter in helping the work of the average informants the informants have more than one social media used to socialize but in helping their informants work more many use WhatsApp as a link. For more details, can be seen in the following table:

Table 2. Social Media besides Email and WhatsApp Used

\begin{tabular}{|l|l|l|l|l|}
\hline NO & Name & $\begin{array}{l}\text { Start used Email } \\
\text { and WhatsApp }\end{array}$ & Group Total & $\begin{array}{l}\text { Other Social } \\
\text { Media }\end{array}$ \\
\hline 1 & Drs. Anwar Sembiring, M.Pd & 2014 & 20 & $\begin{array}{l}\text { FB, Twitter, } \\
\text { Instagram, } \\
\text { Line, } \\
\text { Messenger, }\end{array}$ \\
\hline 2 & $\begin{array}{l}\text { Dr. Hasrat Efendi Samosir, } \\
\text { MA }\end{array}$ & 2015 & 15 & $\begin{array}{l}\text { FB, Twitter, } \\
\text { Instagram, } \\
\text { Line, } \\
\text { Messenger, }\end{array}$ \\
\hline 3 & Rafdinal, S. Sos, M. Ap & 2014 & 17 & $\begin{array}{l}\text { FB, Twitter, } \\
\text { Instagram, } \\
\text { Line, } \\
\text { Messenger, }\end{array}$ \\
\hline 4 & Muhammad Nur & & $\begin{array}{l}\text { FB, Twitter, } \\
\text { Instagram, } \\
\text { Line, } \\
\text { Messenger, }\end{array}$ \\
\hline
\end{tabular}

From the table above it can be seen very clearly if the instant application of e-mail and WhatsApp is very influential on the performance of the Muhammadiyah Regional Leaders of Medan City compared to other applications. It can be seen in the table that the informants not only have one WhatsApp group but more than one group and even up to 25 groups. The informants are also not limited to using just one social media to facilitate their work but they use several social media accounts to support their performance such as Facebook, Line, Instagram, Twitter and Messenger.

Furthermore, the researchers interviewed the informants and revealed that the use of email and WhatsApp was very useful for the informants. Whatsapp is an alternative media choice in the provision of information and performance improvement in organizational programs, especially the Regional Leadership of Muhammadiyah in Medan City. It's just that during the research process it was found that there were differences in the effects felt by one informant and another. The following are excerpts from the interviews of informants:

"WhatsApp messenger is very helpful and facilitates communication both in terms of work and activities that are non-formal in nature such as the relationship between relationships is a media of discussion for members and leaders and this relationship is maintained without having to call and sms using a lot of credit. Because using WhatsApp messenger info we can get a lot of information "

From the explanation above, it can be seen that WhatsApp is one of the social media that can help in completing work, especially in receiving and providing information needed by $\mathrm{Mr}$. Rafdinal. Where communication is easier. Email and WhatsApp seem to be a necessity that has so many benefits. And with this application it is able to change lifestyles and look fresher 
because to access the latest information do not have to wait for conventional letters or open online, and newspapers but simply use e-mail and WhatsApp uploaded by some branch leaders, branch leaders, cadres, and sympathizers.

"The use of WhatsApp is very much felt for me. Information is obtained a lot and is faster than using SMS or other instant messaging services. Email and WhatsApp provide many benefits, most of which facilitate communication. Especially on WhatsApp there is a group name. If there is updated information or invitations and others are directly written in the group. So there is no need to send information one by one to friends via cellphone or SMS. "

As stated by Mr. M. Nur before, and Mr. Rafdinal also said the same thing related to the benefits of e-mail and WhatsApp in providing information that could facilitate information access. Communication becomes easier, even the delivery of information is widespread and fast, it does not have to call or text anymore, but via WhatsApp which is enough to represent, especially with the presence of a wifi network in the office which is very easy. As with the previous informants, they also felt they really needed WhatsApp. From the explanation presented by Mr. Hasrat Efendi Samosir it is very clear that e-mail media and WhatsApp are one of the alternative media and even become the main media in providing information.

Chairman of the Muhammadiyah Regional Office of Medan City, Mr. Anwar Sembiring who uses WhatsApp messenger info also felt the benefits.

"WhatsApp has many benefits for me because it can provide ease of communication even though I am included in the slow use of the WhatsApp application, which is only about three years old but the benefits are very pronounced. By using the program, there are certainly many facilities provided such as telephones, video calls and then we can send large amounts of text such as data and images via pdf or we communicate via video calls so we can quickly send and receive messages compared to using a telephone. And all the facilities on WhatsApp can be used without having to pay dearly enough to fill in the quota, we can connect with others and also connect to the wifi network in the office. Phone contacts are also automatically synchronized with WhatsApp making it easier to contact other friends."

From the interview above, it can be seen that Mr. Anwar Sembiring feels very well how the benefits of the WhatsApp program are very large in him because WhatsApp makes his life easier, especially in communication and information. Another effect is to make himself as if it were a primary need. Without WhatsApp communication with those of other relatives is like being disconnected. Through WhatsApp someone can provide information and get information. This WhatsApp media is one of the media that can provide information.

According to him this program really facilitates communication with friends and family. Another thing that is an advantage of the WhatsApp application is the synchronized automatic telephone contact. This makes it easy for users to connect with other users who are on contact, because contacts that already exist in the phonebook are automatically connected on WhatsApp. Likewise, with our contact number already registered on WhatsApp, it will automatically connect with a friend's account using the WhatsApp application.

The same thing was expressed by Mr. Hasrat Efendi Samosir as Secretary of the Regional Leadership of the Muhammadiyah City of Medan also said:

"WhatsApp is very easy for me to communicate because it is fast and precise, especially in terms of work as a secretary and other jobs. The benefits for me help facilitate communication and obtain information. Especially if helped with other applications such 
as email, with sophisticated and attractive communication facilities. This WhatsApp application turns out to be very easy if we want to see or know information that is updated in the event that the work no longer uses a laptop or waits for circulating letters such as inputting deadline information, in application, work steps, meeting schedules, invitations and so on

The ease of getting information becomes a very strategic thing for the Muhammadiyah Regional Leaders in Medan City according to information from Mr. Hasrat Efendi Samosir. Every activity carried out by the Muhammadiyah Regional Leadership can be conveyed quickly. For example, one of the major programs of the Regional Leaders of Muhammadiyah in the renovation of the Da'wah building was very effective. Renofasi information and restoration of the da'wah building can quickly be connected to all cadres and sympathizers of Medan City through the leadership WhatsApp group, whatshapp group all orthomal organizations and all cadres and sympathizers of Muhammadiyah throughout Medan.

Information built through whatshapp and email media can be well integrated. So that organizational programs run effectively, this is a form of modern administration concept in the era of the current millennial era, all of which requires a fast, precise and accurate time. So the effectiveness of the use of e-mail and WhatsApp is needed and needed for the Muhammadiyah leaders in Medan City.

According to the results of this study, media selection emai and WhatsApp as the main programs for each member of the Muhammadiyah organization are quite numerous and come from various cross-professions and activities, so that many get information related to the current condition of the organization quickly. So it requires effective and relevant mainstream media, e-mail and WhatsApp.

"The effect of using the e-mail and WhatsApp organization on the information synergies of the Regional Leaders of Muhammadiyah in Medan City provides and broadens insights, raises new ideas to be developed and is very interesting, such as organizational development. Then the results of the decision from the Muhammadiyah Central Leadership and the Muhammadiyah North Sumatra Regional Leader can be easily informed by email and whatshapp. Then the new policy or the results of the leadership meeting can be delivered quickly to the leaders and all members. Communication with leaders, assemblies, cadres, orthomas and all sympathizers continues to be well established. Although the information contained in e-mail and WhatsApp organizations is not only information related to organizational programs, but non-formal information is also available such as recitation news, info of death, sad video images or comments from funny cadres. funny or invitation to coffee together. So the nature is also not very rigid about the organization, I consider entertainment readings and additional knowledge so there are no rules in WhatsApp related to the provision of information each member has the same rights. With them commenting for me, I can judge a person's character especially leaders, assemblies, cadres, sympathizers and orthoms. Especially in WhatsApp there are educated and highly educated people who can control negative responses. And related to the amount of information shared in the group sometimes confuses and is not clear especially if we have been pursued deadlines so it takes time to pay attention and select which information is relevant to the needs of the organization. This can happen maybe because there are many members in the group. So many also share information ". 
Based on the results of the study above according to informants' information, researchers can provide some analysis of the use of email usage and which can be seen in the table as follows:

Table 3. Effects of Using Email Usage and WhatsApp

\begin{tabular}{|l|l|l|l|l|}
\hline NO & Name & Speed & Distribution & Selective \\
\hline 1 & Drs.Anwar Sembiring, M.Pd & $*$ & $*$ & $*$ \\
\hline 2 & Dr. Hasrat Efendi Samosir, MA & $*$ & $*$ & $*$ \\
\hline 3 & Rafdinal, S. Sos, M. Ap & & $*$ & $*$ \\
\hline 4 & Muhammad Nur & $*$ & $*$ & $*$ \\
\hline
\end{tabular}

Email and WhatsApp with its features are supported by the ability of the system to operate in a low signal making communication links via email and whatshapp very easy and fast with minimal interference. The result is a lot of information. This condition makes informants increasingly selective in choosing information that is appropriate to be accepted and relevant to the problems experienced related to organizational needs.

All leaders and cadres and sympathizers of Muhammadiyah, especially those who are members of the WhatsApp group, are active in accessing other social media, such as Facebook, line, twitter, BBM, telegram and Instagram, and email is the main device in all applications they use. This is where the highest activity is carried out while carrying out organizational tasks, especially in inputting data or sending documents. They consider social media to be interesting and entertaining and can be a tool to eliminate boredom. With social media they are able to communicate and exchange ideas and discuss with other people even though the person is at a great distance and even people who have never met. The friends who are getting more and more diverse, among them even get information quickly and effectively.

If it is carefully analyzed that the informants also experience the difference in communicating in utilizing email and whatsapp, namely by communicating directly or face to face. This was revealed by all informants that by communicating via email and WhatsApp they were more relaxed, familiar and what they were. But when communicating face to face they feel like there are still barriers that do not make communication flow as is.

The barrier is in the form of feeling reluctant, uncomfortable and awkward. Feelings like this are based on various social conditions that occur, for example social status that distinguishes the position of elements of leaders, assemblies, orthoms, cadres and sympathizers, namely job differences, differences in age, status, gender differences also influence so there is a tendency for communication expressions difficult to express . This condition makes the leaders and assemblies, orthoms and cadres of the Muhammadiyah Regional Leaders prefer to express themselves through communication via email and WhatsApp rather than direct communication (face to face).

Based on the results of the study also stated that leaders, assemblies, orthoms, cadres and sympathizers were more likely to communicate using emial and WhatsApp organizations compared to direct communication with leaders, assemblies, orthoms, cadres and sympathizers in getting the latest information. This is also because informants feel more comfortable communicating via email and WhatsApp. They are better able to be open to others. Moreover, the latest information related to organization is usually shared via email and shared via whatsapp organization. 
The following is a categorization of the findings of interviews from informants based on the use of email usage and WhatsApp organizations.

Table 4. Categorization of Interview Results

Benefits of Email Usage and WhatsApp

\begin{tabular}{|l|l|l|l|}
\hline NO & Name & Position & Interview result \\
\hline 1 & $\begin{array}{l}\text { Drs.Anwar Sembiring, } \\
\text { M.Pd }\end{array}$ & $\begin{array}{l}\text { Head of PDM Medan } \\
\text { City }\end{array}$ & $\begin{array}{l}\text { Quick Access and Low } \\
\text { Cost }\end{array}$ \\
\hline 2 & $\begin{array}{l}\text { Dr. Hasrat Efendi Samosir, } \\
\text { MA }\end{array}$ & $\begin{array}{l}\text { Secretary of PDM PDM } \\
\text { Medan City }\end{array}$ & More Variative Vitur \\
\hline 3 & Rafdinal, S. Sos, M. Ap & $\begin{array}{l}\text { Vice Head of PDM } \\
\text { Medan City }\end{array}$ & $\begin{array}{l}\text { Easy and effective } \\
\text { application }\end{array}$ \\
\hline 4 & Muhammad Nur & $\begin{array}{l}\text { Head office of PDM } \\
\text { Medan City. }\end{array}$ & Faster information \\
\hline
\end{tabular}

Table 5. Categorization of Interview Results

Excess Email Usage and WhatsApp

\begin{tabular}{|l|l|l|l|}
\hline NO & Name & Position & Interview result \\
\hline 1 & $\begin{array}{l}\text { Drs.Anwar Sembiring, } \\
\text { M.Pd }\end{array}$ & $\begin{array}{l}\text { Head of PDM Medan } \\
\text { City }\end{array}$ & More Trend application \\
\hline 2 & $\begin{array}{l}\text { Dr. Hasrat Efendi Samosir, } \\
\text { MA }\end{array}$ & $\begin{array}{l}\text { Secretary of PDM PDM } \\
\text { Medan City }\end{array}$ & Facilitate Coordination \\
\hline 3 & Rafdinal, S. Sos, M. Ap & $\begin{array}{l}\text { Vice Head of PDM } \\
\text { Medan City }\end{array}$ & More convenience \\
\hline 4 & Muhammad Nur & $\begin{array}{l}\text { Head office of PDM } \\
\text { Medan City. }\end{array}$ & Easy and Cheap \\
\hline
\end{tabular}

\section{Conclusion}

The use of email and whatsapp among Muhammadiyah Regional Leaders in Medan City that they understand the reasons for using email and whatsapp as a means of organizational information, the considerations are Trend, Application, Features, Fast and Capacity. Media other than email and whatsapp, they use Facebook, Twitter, Line, Instagram and Messenger. Effects of whatsapp Utilization Used because of its speed, its distribution are easy and can be done selectively. Next the categorization of the utilization of whatsapp used by Muhammadiyah Leaders of Medan City that fast access, low cost, features, more effective and faster information delivered so that it becomes a strategic customer. The advantages of using whatsapp are more trends, easy coordination, more convenience and easier and cheaper. So from this it facilitates organizational activities, connecting quickly with other leaders and mastering the media as a source of effective information and communication within the organization. The messages which is obtained by the Muhammadiyah Regional Head of Medan City from email and whatsapp is that the Leaders can understand the characteristics of Email usage and whatsapp. Next, in the utilization and use of email and whatsapp organizations by 
Muhammadiyah Leaders of Medan City has personal email, organization email and has a WhatsApp group. PDM of Medan City: This group is specifically for the Muhammadiyah Regional Leaders of Medan City. PUSTDAM SUSPIM: This group is for the entire Muhammadiyah Regional Leaders of Medan City, Head and Secretary of the Branch Manager of Muhammadiyah throughout Medan City and Muhammadiyah Branch Leaders throughout Medan City. SURYA PUSDA: This group is all the Muhammadiyah Regional Leaders of Medan City, all Muhammadiyah Branch Heads and Secretaries in Medan City and Muhammadiyah Branch Leaders throughout Medan City and all members of the Muhammadiyah union. Progressing PDM: This group is all Head and Secretary of Muhammadiyah in North Sumatra Regional Leaders. From the two media are used, the message are obtained: Subject, Function, Nature, Intellectual Level, Viewpoint, Quantity, Quality, Boundary Information Time (Date), Speed of Delivery and Processing and Packaging. And the information obtained is discussion via email and WhatsApp, entertaining and about organizational policies.

\section{References}

\section{A. Books}

Abdul Munir Mulkham, Pemikiran Kiai Haji Ahmad Dahlan dan Muhammadiyah Dalam Perspektif perubahan Sosial, Jakarta: Bumi Aksara, 1990.

Ardianto, Elvinaro and Erdinaya, K. Lukiati. Komunikasi Massa Suatu Pengantar, Bandung, Simbiosa Rekatama Media, 2004.

Asymuni Abdurrahman at el, Pedoman Hidup Islami Warga Muhammadiyah, Yogyakarta: Suara Muhammadiyah, 2009.

Andreas Budihardjo, Organisasi: Menuju Pencapaian Kinerja Optimum, Jakarta Selatan, Prasetiya Mulya Publishing: 2011

Abdurrahmat, Organisasi dan Manajemen Sumber Daya Manusia, Jakarta, Rineka Cipta, 2006.

Andreas Budihardjo, Organisasi: Menuju Pencapaian Kinerja Optimum, Jakarta, Prasetiya Mulya Publishing: 2011.

Arif Daryanto, and Heny KS Daryanto. "Model kepemimpinan dan pemimpin agribisnis di masa depan." Bogor: Institut Pertanian Bogor 2004.

Abdul Kadir, Pengenalan Sistem Informasi, Yogyakarta: Andi, 2003.

Andri Kristanto, Perancangan Sistem Informasi, Yogyakarta; Penerbit Gaya Media, 2003.

Alwi Hasan at el, Kamus Besar Bahasa Indonesia, Jakarta: Balai Pustaka, 2005.

Asep Syamsul M. Romli, Journalistik Online : Panduan Praktis Mengelola Media Online . (Bandung : Nuansa Cendekia, 2012.

Ardial, Paradigma dan Model Penelitian Komunikasi, Jakarta: Bumi Aksara, 2014.

Ardianto, Elvinaro and Erdinaya, K. Lukiati. Komunikasi Massa Suatu Pengantar, Simbiosa Rekatama Media, Bandung, 2004.

Biro Pusat Statistik, Beberapa Indikator Penting Sosial Ekonomi Indonesia, Edisi Juli, Balai Penelitian, Jakarta, Eka Media: 2006.

Burhan Bungin, Penelitian Kualitatif, Jakarta : Kencana Prenada Media, 2007

Bob WawoRuntu, "Determinan Kepemimpinan." Jakarta, Makara, Sosial Humaniora 7.2 ; 2003.

Chowdhury, G. G. Introduction to Modern Information Retrieval. London : Library Association Publishing, 2003.

Cholid Narbuko, Metodologi Penelitian, Jakarta : Bumi Aksara, 2013, cet ke 13

Dedi Mulyana, Ilmu Komunikasi, Jakarta : PT. remaja Rosdakarya: 2000.

Departemen Agama RI, Alquran Terjemah Semarang: Toha Putra, 2000. 
Dale F. Eickelman and John W. Anderson, New Media in the Muslim Morld: The Emerging Public Sphere, Bloomington: Indiana University Press, 2003.

Darma, Jarot S., Shenia A, Buku Pintar Menguasai Internet, Jakarta: Media Kita, 2010.

Dayat Kurniawan, Membangun Aplikasi Elektronika dengan Raspberry Pi 2 dan Whasshap, (Jakarta: PT. Elex Media Komputindo, 2016.

Dale F. Eickelman, "New Media in the Arab Middle East and the Emergence of Open Societies", dalam Robert W. Hefner (ed.), Remaking Muslim Politics: Pluralism, Contestation, Democratization, Princeton: Princeton University Press, 2005.

Fraizer Moore, Humas Membangun Citra Dengan Komunikasi, Bandung, Remaja Rosda Karya, 2005. George Caspar Homans, The Human Group (With New Introductions By Paul hare and Ricard Brian Polly), New Brunswick (USA) and London (UK), Library of Congress, Human Geogre Casper: 2009.

Happy Chandraleka, Trik Mengatasi Hacking Email Jakarta, Media Kita, 2009.

Hengky Alexander Mangkulo, Aplikasi Ponsel Gratis Untuk Browsing Dan Email Jakarta: Elex Media Komputindo, 2010.

Hanif Irsyad, Aplikasi Android dalam 5 Menit Edisi Revisi Jakarta: PT. Elex Media Komputindo, 2016.

Herdiansyah, Metode Penelitian Kualitatif, Jakarta, Cipta Media: 2010

Harbani Pasolong, Teori Administrasi Publik, Bandung, Alfabeta: 2007.

Hanif Irsyad, Aplikasi Android dalam 5 Menit Edisi Revisi Jakarta: PT. Elex Media Komputindo, 2016.

Jarot S. \& Sudarma S, Buku Super Pintar Internet Jakarta: Media Kita, 2012.

Jogiyanto HM, Sistem Teknologi Informasi, Yogyakarta : Penerbit Andi , 2003.

J.M. Satteler, Assesment of children behavioral and clinical applications fourth edition. Publiser, Inc: San Diego. 2002

Jalaluddin Rahmat, Psikologi Komunikasi, Jakarta, Raja Grafindo, 2005

--------------, Metode Penelitian Komunikasi. Bandung : PT. Remaja Rosdakarya., 2000.

John W. Anderson, "New Media in the Muslim World: The Emerging Public Sphere", (ISIM Review Vol. 5, 2001.

Jubilee Enterprise, Chatting Tanpa Batas Menggunakan Whatsapp, Jakarta: PT. Elex Media Komputindo, 2014.

John Naisbitt, Mind Set, (terj. Syamsul Wardi), Jakarta: Daras Book, 2009.

John Vivian, Teori Komunikasi Massa. Jakarta : Kencana, 2008.

Jogiyanto Hartono, Sistem Informasi Keperilakuan, Yogyakarta: Andi, 2007.

Jubilee Enterprise, Buku Pintar Blackberry untuk Bisnis, Social Media, dan Fotografi, Jakarta:, PT. Elex Media Komputindo, 2012.

Kismayati El Karimah dan Uud Wahyudin, Filsafat dan Etika Komunikasi,Bandung: Widya Padjadjaran, 2010.

Khomsahrial Romli, Komunikasi Organisasi Lengkap (edisi REVISI) Jakarta, PT. Grasindo, 2014.

Kartini Kartono, Pemimpin Dan Kepemimpinan, Jakarta, PT. Raja Grafindo Persada, 1998.

Lamberton, Lowell H., Human Relation: Strategies for Success, Avenue of The Americas, New York, 2007.

Lev Manovich, "New Media From Borges to HTML." dalam Noah Wardrip-Fruin dan Nick Montfort (eds.), The New Media Reader, Cambridge \& Massachusetts, 2003.

Lexy J. Moleong, Metodologi Penelitian Kualitatif, Bandung: Remaja Rosdakarya, 2005, Cet.X.

------, Metodologi Penelitian Kualitatif Edisi Revisi, Bandung: remaja Rosdakarya, 2006

1997cet. Ke 8

Muwafik Saleh, Komunikasi dalam Kepemimpinan Organisasi, Malang, UB Perss: 2016.

Malayu S.P.Hasibuan, Manajemen Dasar, Pengertian dan Masalah, Jakarta: PT Toko Gunung Agung, 1984.

M Burhan Bungin, Sosiologi Komunikasi, Jakarta: Kencana, 2008.

M.Sobry Sutikno. Pengelolaan Pendidikan, Bandung: Prospect, 2010. 
M. Chazienul Ulum, Perilaku Organisasi Menuju Orientasi Pemberdayaan, Malang, UB Perss, 2016

Miftah Toha, Perilaku Organiasi (Konsep Dasar dan Perilakunya), Jakarta, Raja Grafindo Persada: 2010.

Mohamad Nazir, Metode Penelitian, Bogor: Graha Indonesia, 2005

Nanang Fattah. Landasan Manajeman Pendidikan, Bandung: PT Remaja Rosdakarya Offset, 2013.

Nurudin, Pengantar Komunikasi Massa. Jakarta : Raja Grafindo Persada, 2007.

Nurudin, Pengantar Komunikasi Massa, Jakarta: Rajawali Pers, 2009.

Nurcholis Majid, Khazanah Intelektual Islam, Jakarta: Bulan Bintang, 1984

Onong Efendi Uchayana, Human Relation \& Public Relation, Bandung, Mandar Maju, 2009. , Komunikasi Efektif, Jakarta, Raja Grafindo, 2000.

Pawit M. Yusup, Ilmu informasi, Komunikasi dan Kepustakaan, Jakarta: Bumi aksara, 2009.

Putu Laxman Pendit, Penelitian Ilmu Perpustakaan dan Informasi: Suatu Pengantar Diskusi Epistemologi dan Metodolog, Jakarta: JIP-FSUI, 2003.

Putu Laxman Pendit, Penelitian Ilmu Perpustakaan dan Informasi: Suatu Pengantar Diskusi Epistemologi dan Metodologi, Jakarta: JIP-FSUI, 2003.

R. Soegiatno Tjakra Negara, Hukum tata usaha dan birokrasi Negara. Jakarta, Rineka Cipta: 1992.

Ronny Kountur, Metode Penelitian untuk Penulisan Tesis dan Disertasi, Jakarta : PPM, 2004.

Salam, Metodologi Penelitian Sosial, Bandung: PT Remaja Rosda Karya, 1997

Stephen P. Rubbins, Timothy A. Jugde, Organizational Behavior Edisi 12, diterjemahkan oleh Diana Alngelica, Ria Cahyani dan Abdul Rosuid.

Suharsimi Arikunto, Prosedur Penelitian, Jakarta: Rineka Cipta, 1998

Sondang P. Siagian, Manajemen Sumbar Daya Manusia, Jakarta, Bumi Aksara, 2006.

Su Rahman, Rahasia Membuat Website dengan Modal 200 Ribu, Jakarta, Elex Media Komputindo, 2017.

Sherief Salbino, Buku Pintar Gadget Android Untuk Pemula: Untuk Pemula, Jakarta: Kunci Komunikasi, 2014.

Senja Nila, Rahasia Cara Mudah Chatting dan SMS Unlimited, Jakarta: PT. Elex Media Komputindo, 2012.

Stephen P.Robbins dan Mary Coulter, Manajemen, Edisi Kesepuluh, Jilid 1, Jakarta: PT. Gelora Aksara Pratama: 2010.

Sutarto, Dasar-dasar Kepemimpinan Administrasi, Yogjakarta, Gajah Mada University Press: 1986.

Sugiono, Metode Penelitian Kombinasi, Bandung : Alfabeta, 2011.

Soerjono Soekamto, Pengantar Penelitian Hukum, Jakarta: UI Press, 1986.

Safidin Azwar, Metodologi Penelitian, Yogyakarta: Pustaka Pelajar, 1998.

Suharmi Arikunto, Prosedur Penelitian: Suatu Praktek, Jakarta : Rineka Cipta, 1990.

Veithzal Rifai, Manajemen Sumber Daya Manusia untuk Perusahaan, Jakarta, Rajawali, 2011.

Veithzal Rivai, Kepemimpinan dan Perilaku Organisasi, Jakarta: PT. Raja Grafindo Persada, 2012.

Wibowo, Perilaku Dalam Organisasi, Jakarta: PT. Raja Grafindo Persada, 2013.

Wilson, T.D., "Models in Information Behavior Research". Journal of Documentation. Volume 55 No 3: 1999

Wahyudi, Komuninasi dan Informasi, Bandung, Insan Perss, 2001.

Wursanto, Dasar-dasar Ilmu Organisasi Yogyakarta: Andi: 2005.

Yusufhadi, Media Pembelajaran, Jakarta, Cipta Pustaka: 1994

Zaki, Telekomunikasi Abad Modern, Jakarta, Media Perintis: 2010

\section{B. Journals}

Belkin, N.J., "Information Concept for Information Science", Journal of Documentation, Vol. 34 Issue 1: 1978.

Eka Cahyani at el., Pengaruh Human Relation (Hubungan Antar Manusia) Dan Kondisi Lingkungan Kerja Terhadap Kinerja Karyawan (Studi Pada Karyawan Dinas Pekerjaan Umum Cipta Karya Kabupaten Lamongan), Journal Administrasi Bisnis (JAB), Vol. 17 No. 2, December 2014. 
Kuhlthau, Carol C, "Inside the Search Process: Information Seeking from the Users Perspective". Journal of the American Society for Information Science, Volume 42 No. 5: 1991.

Ruggiero, Thomas E. Uses and Gratification Theory in the $21^{\text {st }}$ Century. Journal Mass Communication \& Society : University of Texas, 2000.

Soleh Rosyad at el., Pengaruh Human Relation Terhadap Prestasi Kerja Pegawai Dinas Pendapatan Dan Pengelolaan Keuangan Daerah Di Kabupaten Lebak, E-jurnal Management, Volume 1 No. $2,2012$.

\section{Journal Resources and Research Results}

Derry Mayendra, Pengaruh Kredibilitas Berita Politik Dalam Media Online Okezone.com Terhadap Preferensi Pengguna. Penulisan Ilmiah : Universitas Gunadarma, 2013.

Ishak, Kebutuhan Informasi Mahasiswa Program Pendidikan Dokter Spesialis (PPDS) FK. UI dalam memenuhi Tugas Journal Reading. Pustaha. Vol.2, No.2, Dec. 90-101, 2006.

Irwansyah, Teknologi Komunikasi Sebagai Eksistensi Kekerabatan: Studi Analisa Jaringan Sosial Kekerabatan Berbasis Teknologi Komunikasi Telepon Seluler, Jakarta, Universitas Indonesia, 2010.

Prahatmaja, Nurmaya. Studi Tentang Karakteristik Individu Dan Karakteristik Sosial Masyarakat Kampung Naga dan Kaitannya Dengan Pola Pertukaran Informasi, (Jakarta, Hasil Penelitian Balai LITBANG: 2006.

Riady, Yasir, Perilaku pencarian Informasi Mahasiswa Program Doktoral Dalam Penyusunan Disertasi, Visi Pustaka, Vol. 15, No. 2, August 2013.

D. Internet Resources

This article has been aired on Kompas.com with the title "Pengguna Aktif Bulanan WhatsApp Tembus 1,5 Miliar", https://tekno.kompas.com/read/2018/02/01/09270377/pengguna-aktif-bulananwhatsapp-tembus-15-miliar. Penulis : Fatimah Kartini Bohang. Accessed on 27 February 2019 at $21.42 \mathrm{Wib}$

This data can be accessed https://inet.detik.com/cyberlife/d-3912429/130-juta-orang-indonesiatercatat-aktif-di-medsos, di akses 27 Pebruari 2019 pada pukul 21.23 Wib

Encang Saepudin, Prilaku Pencarian dalam Memenuhi Kebutuhan Informasi (Bagian I), 2009 http://encangsaepudin.wordpress.com/2009/01/10/prilaku-pencariandalam-memenuhikebutuhan-informasi-bagian-1/, Accessed on 22 September 2019

file:///C:/Users/Win\%207/Downloads/1980-4140-1-PB.pdf

Google Play Store is one of the various media distribution platforms and applications by Google that are most used by Android users, Accessed on https://play.google.com/store.

Gmail Dominasi Jasa Layanan Email di Indonesia , Accessed on 23 February 2019 at15.18 Wib https://databoks.katadata.co.id/datapublish/2016/10/28/gmail-dominasi-jasa-layanan-email-diindonesia

http://eprints.umm.ac.id/24848/, Accessed on 21 August 2018 at 11.47 WIB.

http://eprints.umm.ac.id/24848/, Accessed on 21 August 2018 at 11.47 WIB

http://digilib.unhas.ac.id/uploaded_files/temporary/DigitalCollection/YjI5ZDdmNGMyZDFmYzAwZ jY0ZTY2Y2UyMjU5NzU0NDk1NmUyMTRmYw==.pdf

The first conference in 1980 was in the background of the Iranian Revolution in 1979. At that time the mass mobilization of the monarchist regime of the reigner Shah Reza Pahlevi was mobilized through smuggling of lecture tapes, bulletins, newspapers, and leaflets of Imam Khomeini from exile in Iraq and France. After a period of 30 years, a second conference was held, showing that Muslims ignored the importance of media development in accelerating changes in society. Natana J. DeLong-Bas, The New Social Media and the Arab.Springhttp://www.oxfordislamicstudies.com/Public/focus/essay0611_social_media.htm. Accessed on 30 July 2018.

Paul Emerson Teusner and Heidi A. Cambell, Religious Authority in the Age of the Internet, http//www.baylor.edu., hlm, 65-66, Accessed on 1 August 2018 
Wilson, "Human Information Behavior". Informing science. 3(2): p.49-56, 2000http://inform.nu/Articles/Vol3/v3n2p49-56.pdf, Accessed on 20 September 2018.

\section{E. Source of interview}

Interview with Mr. M. Nur Head Office and Amin Group WA Muhammadiyah Regional Head of Medan City at Muhammadiyah Regional Office of Medan City Road Mandala by Field Pass on Friday January 4, 2019 At 10:30 to 12:00 WIB

Interview with Mr Anwar Sembiring Chairperson of the Medan Muhammadiyah Regional Leadership at the Medan City Muhammadiyah Regional Leadership Office Jalan Mandala by Pass Medan on Monday 7 January 2019 at 16:30 a.m. to 5:35 p.m.

Interview with Mr. Rafdinal as Deputy Chairperson of the Muhammadiyah Regional Head of Medan City at Muhammadiyah Middle School 01 Jalan Demak Medan Kota on Friday, January 4, 2019 At 10:30 a.m. 12.00 WIB.

Interview with Mr. Hasrat Efendi Samosir as the secretary of the Muhammadiyah Regional Head of Medan City, at his Tembung VII Market Simple Street in Percut Sei District, Deli Serdang District, on Thursday, January 3, 2019. 